\title{
Phoretic association between Hisonotus chromodontus (Loricariidae: Hypoptopomatinae) and Ichthyocladius sp. (Diptera: Chironomidae) larvae in Amazonian streams
}

\author{
Andressa Cristina Costa ${ }^{1,2}{ }^{\circledR}$, Fábio Martins de Almeida ${ }^{2}$, João Otávio Santos Silva ${ }^{2,3}$, Talles Romeu \\ Colaço-Fernandes $^{2}$ \& Lucélia Nobre Carvalho ${ }^{1,2 *(1)}$ \\ ${ }^{1}$ Universidade Federal de Mato Grosso, Programa de Pós-Graduação em Ciências Ambientais, Campus \\ Universitário de Sinop, Sinop, MT, Brasil. \\ ${ }^{2}$ Universidade Federal de Mato Grosso, Instituto de Ciências Naturais, Humanas e Sociais, Laboratório de \\ Ictiologia Tropical, Campus Universitário de Sinop, Sinop, MT, Brasil. \\ ${ }^{3}$ Universidade Estadual de Maringá, Núcleo de Pesquisas em Limnologia, Ictiologia e Aquicultura, Laboratório \\ de Ictioparasitologia, Programa de Pós-Graduação em Ecologia de Ambientes Aquáticos Continentais, \\ Maringá, PR, Brasil. \\ *Corresponding author: carvalholn@yahoo.com.br
}

COSTA, A.C., ALMEIDA, F.M., SILVA, J.O.S., COLAÇO-FERNANDES, T.R., CARVALHO, L.N. Phoretic association between Hisonotus chromodontus (Loricariidae: Hypoptopomatinae) and Ichthyocladius sp. (Diptera: Chironomidae) larvae in Amazonian streams. Biota Neotropica 21(3): e20201140. https://doi.org/10.1590/1676-0611-BN-2020-1140

\begin{abstract}
Larvae of non-biting midges in the family Chironomidae can be found in association with several species of fish in the family Loricariidae. In this study, we describe the first record of phoretic interaction between larvae of Ichthyocladius sp. and the fish Hisonotus chromodontus in streams in the Amazon basin. Between July 2010 and March 2019, fish were collected from three streams of the Teles Pires River basin in the state of Mato Grosso, Brazil. We investigated the attachment site of chironomid larvae on the body of fish and the frequency of attachment. A total of 1.241 specimens of $H$. chromodontus were collected, among which nine hosts were found carrying in the ventral region a single Ichthyocladius sp. specimen. All Ichthyocladius sp. were attached to a spicule of fish between the pectoral and pelvic fins, in which they were observed at the fourth developmental stage at the beginning of the cocoon construction $(1.50 \mathrm{~mm})$. In addition, a pre-pupa larva $(2.60 \mathrm{~mm})$ and an empty cocoon $(2.50 \mathrm{~mm})$ were reported. The Loanda stream had the highest occurrence of this type of association (of 12 fish examined, three had larvae). The other two streams reported a lower occurrence: the Baixada Morena stream had three fish associated with larvae amongst 1105 fish examined, whereas the Selma stream had three out of 124 fish infested by larvae. The occurrence of only one larva per host can be related to the small body area of the host fish (average standard length $=26.60 \mathrm{~mm}$ and average weight $=0.31 \mathrm{~g}$ ). We observed that the larvae prefer fixation sites in the vicinity of the pectoral and pelvic fin of the fish, which is presumably associated with the fact that chironomids feed on algae and debris suspended by the movement of loricariids. These streams differ with respect to the presence of riparian forests, which may affect resource availability and thereby influence ecological interactions between the species.

Keywords: Interspecific Interaction; Invertebrate-fish Interaction; Phoresy; Tapajos River basin; Non-biting midges; Siluriformes.
\end{abstract}

\section{Associação forética entre Hisonotus chromodontus (Loricariidae: Hypoptopomatinae) e larvas de Ichthyocladius sp. (Diptera: Chironomidae) em riachos amazônicos}

\footnotetext{
Resumo: Larvas de mosquitos da família Chironomidae podem ser encontradas em associação com várias espécies de peixes da família Loricariidae. Neste estudo, descrevemos o primeiro registro de interação forética entre larvas de Ichthyocladius sp. e o Hisonotus chromodontus em riachos da bacia amazônica. Entre julho de 2010 e março de 2019, foram coletados peixes em três riachos da bacia do rio Teles Pires, no estado de Mato Grosso, Brasil. Nós investigamos o local de fixação das larvas de quironomídeos no corpo dos peixes e a frequência da fixação. Um total de 1.241 espécimes de H. chromodontus foram coletados, entre os quais nove hospedeiros foram encontrados
} 
carregando, na região ventral, um único espécime de Ichthyocladius sp. Todos os Ichthyocladius estavam aderidos a uma espícula do peixe entre as nadadeiras peitoral e pélvica, onde foram observados no quarto estágio de desenvolvimento, no início da construção do casulo $(1,50 \mathrm{~mm})$, além de uma pré-pupa $(2,60 \mathrm{~mm})$ e um casulo vazio $(2,50 \mathrm{~mm})$. O riacho Loanda apresentou a maior ocorrência de hospedeiros na associação (de 12 peixes examinados, três estavam com larvas) e o menor registro foi para o riacho Selma (dos 1105 peixes examinados, três estavam infestados). A ocorrência de apenas uma larva por hospedeiro pode estar relacionada à pequena área corporal do peixe hospedeiro (comprimento padrão médio $=26,60 \mathrm{~mm}$ e peso médio $=0,31 \mathrm{~g}$ ). Observamos que as larvas preferem locais de fixação nas proximidades da nadadeira peitoral e pélvica dos peixes, o que está presumivelmente associado ao fato dos quironomídeos se alimentarem de algas e detritos suspensos pelo movimento dos loricarídeos. Os riachos diferem com relação à presença de matas ciliares, que podem afetar a disponibilidade de recursos e, assim, influenciar as interações ecológicas entre as espécies.

Palavras-chave: Interação Interespecifica; Interação Invertebrado-peixe; Forésia; Bacia do rio Tapajós; Mosquitos; Siluriformes.

\section{Introduction}

Ecological interactions can be considered harmonious, such as commensalism and mutualism, or discordant, such as parasitism and predation (Ricklefs \& Relyea 2016). Phoresy is a form of temporary interspecific commensalism, in which a phoretic organism enters an association with another organism for purpose of dispersal, with no harm being caused to its host or disruption of trophic processes (Hunter \& Rosario 1988, Houck \& O’Connor 1991, Bartlow \& Agosta, 2021). Phoretic interactions have been documented mostly in terrestrial taxa (Badets \& Du Preez 2014, White et al. 2017, Bartlow \& Agosta, 2021). In freshwater environments, porpoises carrying candirus fish (Araújo-Wang et al. 2019), several species of fish carrying candirus fish (Zuanon \& Sazima 2005, Adriaens et al. 2010), and mussel larvae as phoretic organisms on fish (Modesto et al. 2018) have been recorded. Furthermore, interactions between non-biting midges larvae and freshwater fish provide examples of phoretic associations between fish and insects (Fittkau 1974, Pinder 1986, Mendes et al. 2004, Trivinho-Strixino 2014).

Non-biting midges in the family Chironomidae (Diptera) can typically be found in sediments and on aquatic vegetation but can also enter phoretic associations with other aquatic organisms (TrivinhoStrixino 2014). For example, the larvae of Ichthyocladius Fittkau 1974 (Chironomidae: Orthocladiinae) and others larvae midges belonging to this group have been observed in association with the siluriformes fish of families Astroblepidae, Loricariidae, and Trichomycteridae (Fittkau 1974, Pinder 1986, Mendes et al. 2004, Trivinho-Strixino 2014). Loricariidae fish (armored catfish) have been described as hosts of Ichthyocladius larvae, including Ancistrus, Chaetostoma, Corumbataia, Harttia, Hemipsilichthys, Hisonotus, Hypostomus, Kronichthys, Neoplecostomus, Otothyropsis, Pareiorhaphis, and Pareiorhina (Vilella 2002, Mendes 2004, Roque et al. 2004, Sydow et al. 2008, HenriquesOliveira \& Nessimian 2009, Dala-Corte \& Melo 2018, Mattos et al. 2018). The first observations of phoretic interactions between loricariids and Ichthyocladius larvae were recorded in rivers of the Amazon basin (Freihofer \& Neil 1967), whereas in Brazil, other occurrences have recorded in the south (Vilella 2002, Sydow et al. 2008, Dala-Corte \& Melo 2018) and southeast Atlantic watersheds (Mendes 2004, Roque et al. 2004, Henriques-Oliveira \& Nessimian 2009, Mattos et al. 2018).

During previous ecological studies on streams in the Teles Pires River sub-basin, we collected specimens of the loricariid fish Hisonotus chromodontus Britski \& Garavello 2007 (Loricariidae:
Hypoptopomatinae), a species restricted to the Tapajos basin, Amazonia (Dagosta \& de Pinna 2019), some of which were unexpectedly found to be transporting Ichthyocladius sp. larvae. In the present study, we provide the first record of the phoretic association between $H$. chromodontus and Ichthyocladius sp. in streams of the South Amazon.

\section{Material and Methods}

\section{Study area}

Between July 2010 and March 2019, we collected fish from three first- to third-order streams, the Loanda $\left(11^{\circ} 25^{\prime} 33.1^{\prime \prime} \mathrm{S}\right.$ and $\left.55^{\circ} 16^{\prime} 39.3^{\prime \prime} \mathrm{W}\right)$, Baixada Morena $\left(11^{\circ} 29^{\prime} 43.9^{\prime \prime} \mathrm{S}\right.$ and $\left.55^{\circ} 21^{\prime} 44.0^{\prime \prime} \mathrm{W}\right)$ and Selma $\left(11^{\circ} 36^{\prime} 03.2^{\prime \prime} \mathrm{S}\right.$ and $\left.55^{\circ} 25^{\prime} 41.5^{\prime \prime} \mathrm{W}\right)$, which are tributaries of the right bank of the Teles Pires River and differ among them in relation to preservation. The Loanda stream is characterized by an intact riparian forest, sandy substrate, and an absence of macrophytes (Cabeceira 2014), whereas the Selma stream lacks riparian forest and has areas of rapids, sand, and pebble substrate, and supports the growth of macrophytes. The Baixada Morena stream is also devoid of riparian forest in the area sampled and is considered to have undergone considerable environmental damage.

\section{Fish collection and recording of fish-insect interactions}

Fish were collected by two or three individuals using 0.5 -mm-mesh nets. The collected specimens were euthanized with Eugenol anesthetic, fixed in formalin solution (10\%), and subsequently transferred to $70 \%$ ethanol (modified from Mendonça et al. 2005). Voucher specimens were deposited in the fish collection of the Tropical Ichthyology Laboratory (LIT) of the Federal University of Mato Grosso, Sinop University Campus (voucher specimens with fixed larvae: LIT 3143, LIT 3144 and LIT 3145), and at the Ichthyological Collection of the Center of Research in Limnology, Ichthyology and Aquaculture (NUPELIA) of the State University of Maringá (voucher specimens: NUP 22680). The fish were weighed $(\mathrm{g})$, measured $(\mathrm{mm})$, examined for the presence of chironomid larvae, and photographed with the aid of Leica S9 stereomicroscope $(\times 50$ magnification) to record development (larval and pupal phases) (TrivinhoStrixino 2014) and the sites of attachment of phoretic organisms on fish.

The larvae were identified to the genus level by using morphological character-based identification keys presented by Trivinho-Strixino 
(2014). According to Trivinho-Strixino (2014) and Luiz Carlos de Pinho (personal communication) the identification of immature chironomid species (larvae and pupae), is only possible through the observation of the male genitalia adult.

\section{Results}

A total of 1.241 specimens of $H$. chromodontus, with mean standard lengths and weights ranging from 27 to $38 \mathrm{~mm}$ and 0.19 to $0.38 \mathrm{~g}$, were collected. Among these, nine fish were found to be carrying a single Ichthyocladius sp. larva. The Loanda and Selma streams had the highest (of 12 fish examined, three had larvae) and the smallest (of the 1105 fish examined three fish were infested) occurrence of the interaction, respectively (see Table 1). All chironomids were observed in the ventral region between the pectoral and pelvic fins to the host (Figure $1 \mathrm{a}$ ), attached by fixing the distal part of the abdomen (prolegs) to the fish spicule, leaving the larval head free (Figure 1b). Attached Ichthyocladius sp. were observed at the fourth developmental stage at the beginning of the cocoon construction (Figure $2 \mathrm{a}$ and $\mathrm{b}$ ). In addition, we found a pre-pupa larva (Figure $2 \mathrm{c}$ ) and an empty cocoon (Figure $2 \mathrm{~d}$ ).

\section{Discussion}

We report here the first record of phoresy between insect-fish for the South of the Brazilian Amazon, involving a loricariid host with restricted distribution in the Tapajós River basin. Free-living larvae of chironomidae (Figure S1) has limited dispersal capacity and the interactions with a fish can benefit it with no detrimental effects on their fish hosts. The phoresy recorded in this study represents a commensal interaction that benefits chironomid larvae (White et al. 2017, Silknetter et al. 2020). The findings of the present study, in which we detected only a single larva attached to each host, contrast with those of other studies that have reported means of 12.21 (Sydow et al. 2008) and 13.2 (Mattos et al. 2018) Ichthyocladius larvae associated with loricariid fish species. These studies have described loricariid hosts with relatively large body lengths of $104 \mathrm{~mm}$ (Sydow et al. 2008), $93 \mathrm{~mm}$ (DalaCorte \& Melo 2018), and $63 \mathrm{~mm}$ (Mattos et al. 2018), compared with the maximum length of $43 \mathrm{~mm}$ SL for the Hisonotus chromodontus specimens collected in the three streams we investigated.

Sydow et al. (2008) examined the relationship between the total length of three species of loricariid (Ancistrus cf. multispina (104.2 mm), Pareiorhaphis hypselurus (62.5 mm), and Pareiorhaphis nodulus (37.6 $\mathrm{mm})$ ) and the quantity of associated chironomids. The larval density is higher in larger fish; for example, $P$. nudulus (a host with two larvae) had a mean length three times shorter than that of the other two species, as Pareiorhaphis hypselurus and Ancistrus cf. multispina, which had the density of larvae of 2.57 and 12.21, respectively. Similarly, Dala-Corte \& Melo (2018) examined the distribution of Ichthyocladius larvae on the loricariid Pareiorhaphis hypselurus and found that smaller $(36 \mathrm{~mm})$ and larger $(93 \mathrm{~mm})$ fish had correspondingly small and large chironomid infestations, respectively. Large-sized hosts can carry a larger number of chironomid larvae on their body because they have a greater surface area, as well as a greater swimming range, thereby providing phoretic organisms with access to the larger amounts of suspended food particles (Sydow et al. 2008, Dala-Corte \& Melo 2018).

The Ichthyocladius larvae associated with fish gain advantages with respect to diet (continuous access to debris and algae available on the host body), mobility (avoiding unfavorable habitat sites), protection against predators (larvae are camouflaged by the host) and environmental disturbance (commensal species vulnerable to environmental disturbance exploit hosts to evade areas exposed to such disturbance) (Tokeshi 1993). As observed herein, larvae prefer attachment sites in the vicinity of pectoral and pelvic fin of fish, which is presumably associated with the fact that chironomids feed on algae and debris suspended by the movement of loricariids (Henriques-Oliveira et al. 2003, da Silva et al. 2008, Sydow et al. 2008, Mattos et al. 2018). Ichthyocladius larvae have thick posterior pseudopods bearing strong claws that facilitate attachment to the host, and construct cocoons shaped like fish scales attached to the spines of host fish fins (Trivinho-Strixino 2014). In this regard, it can be speculated that the symbionts have preferred sites for attachment on the surface of the host body and that there is competition for these sites. Alternatively, larvae may not show any site-specific preference and colonize all sites equally but remain attached to those sites that offer better resources or protection against predators (Dala-Corte \& Melo 2018). The dispersal of an organism by phoretic interaction involves locating, fixing and detaching from the host (Bartlow \& Agosta 2021). The success of this interaction is clear from our findings, as we found both larvae in the initial fixation phase and an empty cocoon trapped in the host.

Hisonotus species feed on periphyton, with a diet composed of diatoms, Chlorophyceae, and organic matter (Casatti 2002, Teresa \& Casatti 2012), and numerous studies have shown that the availability of periphyton in streams is dependent on riparian coverage and may influence the growth of loricariid fish species with this type of diet (Bojsen \& Barriga 2002, Teresa \& Casatti 2012, Fernandes et al. 2013, Gomes et al. 2020). Therefore, it is possible that the degradation of the vegetation cover has a negative influence on the ecological interactions of the streams studied here.

\section{Supplementary Material}

The following online material is available for this article:

Table 1. Occurrence of Ichthyocladius sp. larvae on the loricariid Hisonotus chromodontus in three streams in the Teles Pires River basin. SL $=$ standard length $(\mathrm{mm}) ; \min =$ minimum; $\max =$ maximum.

\begin{tabular}{lccccc}
\hline Stream & $\begin{array}{c}\text { Number of } \\
\text { H. chromodontus collected }\end{array}$ & $\begin{array}{c}\text { SL (mm) Average } \\
(\mathbf{m i n}-\mathbf{m a x})\end{array}$ & Weight (g) Average (min-max) & Hosts & Larvae \\
\hline Selma & 1105 & $21.95(17.83-26.40)$ & $0.19(0.07-0.32)$ & 3 & 3 \\
Baixada Morena & 124 & $27.90(26.73-29.31)$ & $0.38(0.35-0.42)$ & 3 & 3 \\
Loanda & 12 & $29.90(26.60-35.10)$ & $0.36(0.32-0.40)$ & 3 & 3 \\
Total & 1241 & 26.6 & 0.311 & 9 & 9 \\
\hline
\end{tabular}


Costa, A.C. et al.

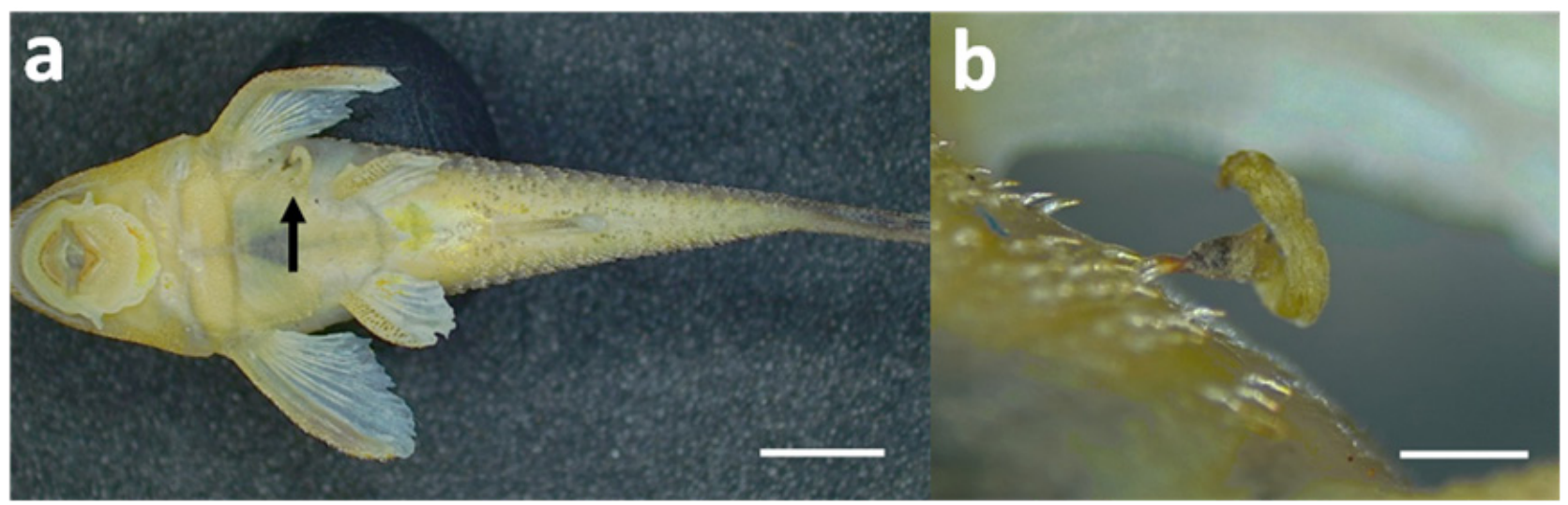

Figure 1. Ventral view of Hisonotus chromodontus ( $26 \mathrm{~mm}$ SL and $0.18 \mathrm{~g}$ weight) with an arrow indicating the position of a larvae of Ichthyocladius sp. between pectoral and pelvic fins, (a) Ichthyocladius sp. larva $(2.10 \mathrm{~mm}$ ) attached to a distal part of the abdomen (proleg) to a spicule (b). Scale bar: $1 \mathrm{~mm}$.

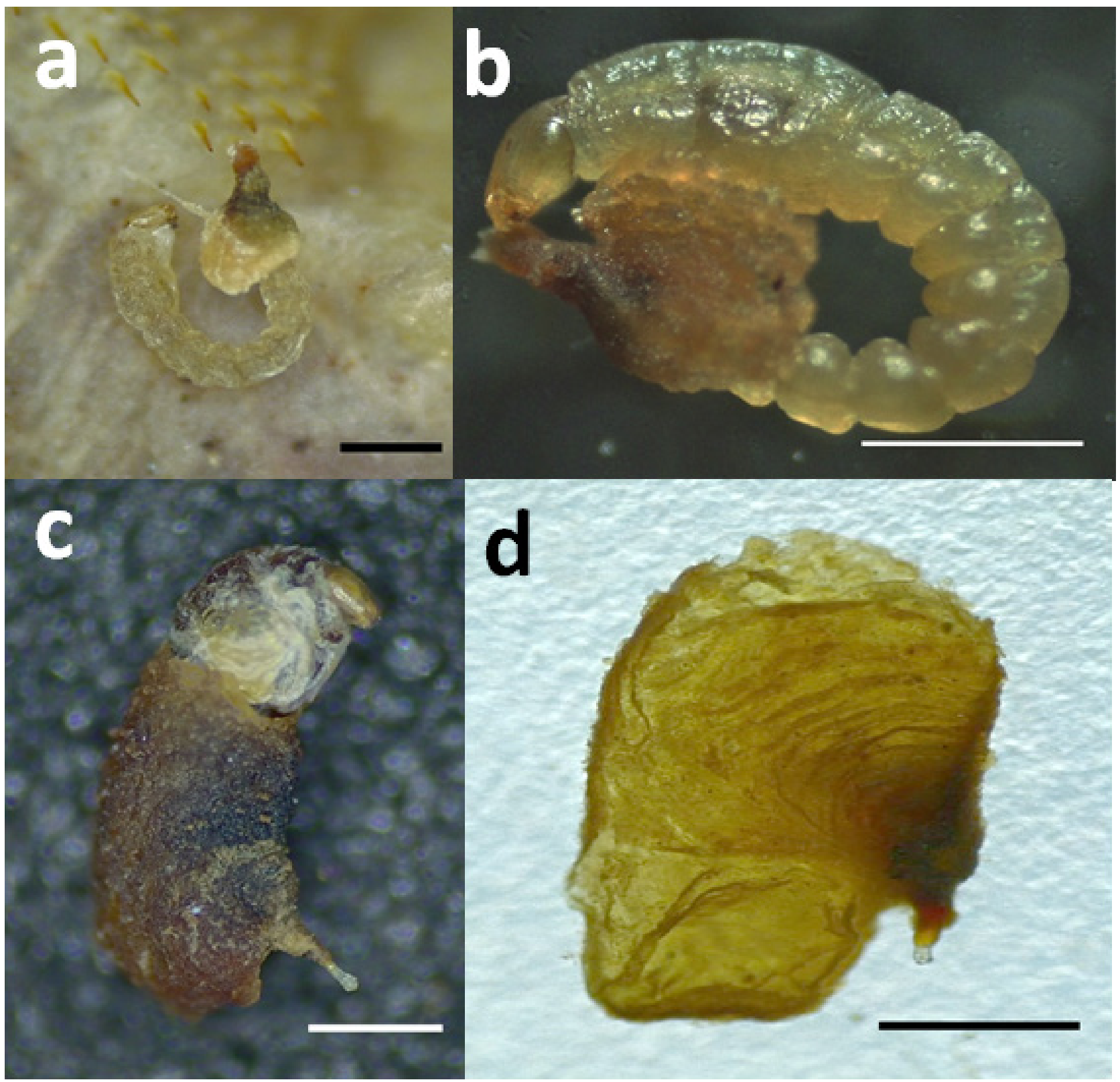

Figure 2. Ichthyocladius sp. development phases: (a) larva $(1.10 \mathrm{~mm})$ attached on the distal part of the abdomen, (b) initial pupal phase (1.50 mm), (c) prepupal $(2.60 \mathrm{~mm})$, (d) empty cocoon $(2.50 \mathrm{~mm})$. Scale bar: $1 \mathrm{~mm}$. 
Figure S1 - Free-living larvae of Ichthyocladius sp. (indicated by arrow) fixed in a submerged log near two specimens of Hisonotus chromodontus in an Amazonian stream.

\section{Acknowledgements}

We thank Jorge Luiz Nessimian for the valuable critical review of the manuscript. Animal capture was authorized by permit (\# 18924-1) from ICMBio- Instituto Chico Mendes de Conservação da Biodiversidade. This research is part of a master's thesis by the first author, with the support of the Universidade Federal de Mato Grosso (UFMT). The study was financed by the Coordination for the Improvement of Higher Education Personnel Brasil (CAPES) - Finance Code 001 for Andressa Cristina Costa (Process number: 88887.496222/2020-00).

\section{Author Contributions}

Andressa Cristina Costa: Substantial contribution in the concept, design of the study, data collection, data analysis, interpretation and manuscript preparation.

Fábio Martins de Almeida: Substantial contribution in the concept, design of the study, data collection, data analysis and interpretation.

João Otávio Santos Silva: Contribution to data collection, critical revision and adding intellectual content.

Talles Romeu Colaço-Fernandes: Contribution to data collection, critical revision and adding intellectual content.

Lucélia Nobre Carvalho: Substantial contribution in the data analysis, interpretation, manuscript preparation, critical revision, funding acquisition and academic supervision.

\section{Conflicts of Interest}

The authors declare that they have no conflict of interest related to the publication of this work.

\section{References}

ADRIAENS, D., BASKIN, J. N. \& H. COPPENS. 2010. Evolutioary morphology of trichomycterid catfishes: about hanging on and digging. In Origin and phylogenetic interrelationships of teleosts (S. Nelson, H. P. Schultze \& M. V. H. Wilson, eds). Munchen: Verlag Dr. Friedrich Pfei, p.337-62.

ARAÚJO-WANG, C., SCHORMANS, E. K. \& WANG, J. Y. 2019. Ecological interaction of a "parasitic" candiru catfish and botos (Inia geoffrensis). Marine Mammal Science 35(4): 1347-1354.

BADETS, M. \& DU PREEZ, L. 2014. Phoretic interaction between the kangaroo leech Marsupiobdella africana (Hirudinea: Glossiphoniidae) and the cape river crab Potamonautes perlatus (Decapoda: Potamonautidae). International Journal for Parasitology: Parasites and Wildlife 3(1): 6-11.

BARTLOW, A. W. \& AGOSTA, S. J. 2021. Phoresy in animals: review and synthesis of a common but understudied mode of dispersal. Biological Reviews 96(1): 223-246.

BOJSEN, B. H. \& BARRIGA, R. 2002. Effects of deforestation on fish community structure in Ecuadorian Amazon streams. Freshwater Biology 47: $2246-2260$

BRITSKI, H. A. \& GARAVELLO, J. C. 2007. Description of two new sympatric species of the genus Hisonotus Eigenmann and Eigenmann, 1889, from upper Rio Tapajós, Mato Grosso state, Brazil (Pisces: Ostariophysi: Loricariidae). Brazilian Journal of Biology 67(3): 413-420.
CABECEIRA, F. G. 2014. Relações entre estrutura do habitat, composição taxonômica e trófica de peixes em riachos da bacia do rio Teles Pires, Amazônia Meridional. Master's Dissertation. Universidade Federal de Mato Grosso. (last accessed on 19/03/2020).

CASATTI, L. 2002. Alimentação dos peixes em um riacho do Parque Estadual Morro do Diabo, bacia do Alto Rio Paraná, sudeste do Brasil. Biota Neotropica 2(2): 1-14. https://doi.org/10.1590/S1676-06032002000200012 (last access on 01/09/2020)

DAGOSTA, F. C. \& DE PINNA, M. 2019. The fishes of the Amazon: Distribution and biogeographical patterns, with a comprehensive list of species. Bulletin of the American Museum of Natural History 2019(431): 1-163.

DALA-CORTE, R. B. \& MELO, A. S. 2018. Living on a catfish: nested occupation of ectosymbiotic chironomids on host body. Canadian Journal of Zoology 96(7): 692-699.

DA SILVA, F. L., MOREIRA, D. C., BOCHINI, G. L. \& RUIZ, S. S. 2008. Hábitos alimentares de larvas de Chironomidae (Insecta: Diptera) do córrego Vargem Limpa, Bauru, SP, Brasil. Biotemas 21(2): 155-159.

FERNANDES, I. M., LOURENÇO, L. S., OTA, R. P., MOREIRA, M. M. \& ZAWADZKI, C. H. 2013. Effects of local and regional factors on the fish assemblage structure in Meridional Amazonian streams. Environmental Biology of Fishes 96(7): 837-848.

FITTKAU, E. J. 1974. Ichthyocladius n. gen., eine neotropische Gattung der Orthocladiinae (Chironomidae, Diptera) deren Larven epizoisch auf Welsen (Astroblepidae und Loricariidae) leben. Nordisk Hygienisk Tidskrift. Supplementum 95: 91-106.

FREIHOFER, W. C. \& NEIL E. H. 1967. Commensalism between midge larvae (Diptera: Chironomidae) and catfishes of the families Astroblepidae and Loricariidae. Copeia 1: 39-45.

GOMES, A. C. A. M., GOMES, L. F., ROITMAN, I., PEREIRA, H. R., JUNIOR, A. F. C., da COSTA, E. M. M., da SILVA, M. L. C., JACOBSON, T. K. B., da COSTA RIBEIRO, R. J., de MIRANDA FILHO, R. J., de AVILA, M. L. \& VIEIRA, L. C. G. 2020. Forest cover influences zooplanktonic communities in Amazonian streams. Aquatic Ecology 54(4): 1067-1078.

HENRIQUES-OLIVEIRA, A. L., NESSIMIAN, J. L. \& DORVILLÉ, L. F. M. 2003. Feeding habits of chironomid larvae (Insecta: Diptera) from a stream in the Floresta da Tijuca, Rio de Janeiro, Brazil. Brazilian Journal of Biology 63(2): 269-281.

HENRIQUES-OLIVEIRA, A. L. \& J. L. NESSIMIAN. 2009. Phoresy and commensalism of Chironomidae larvae (Insecta: Diptera) in the state of Rio de Janeiro, Brazil. Lundiana 10(1): 11-18

HOUCK, M. A. \& OCONNOR, B. M. 1991. Ecological and evolutionary significance of phoresy in the Astigmata. Annual review of entomology 36(1): 611-636.

HUNTER, P. E. \& ROSARIO, R. M. T. 1988. Associations of Mesostigmata with other arthropods. Annual Review of Entomology 33(1): 393-417.

MATTOS, T. M., CARVALHO, D. R., BRITO, M. S. D. \& ARAÚJO, F. G. 2018. Occurrence of phoresy between Ancistrus multispinis (Actinopterygii: Siluriformes) and Ichthyocladius sp. (Diptera: Chironomidae) in Atlantic forest streams. Southeast Brazil Zoologia 35: 1-6.

MENDES, H. F., ANDERSEN, T. \& Saether, O. A. 2004. New species of Ichthyocladius Fittkau, a member of the Corynoneura-group (Diptera: Chironomidae: Orthocladiinae), with a review of the genus. Studies on Neotropical Fauna and Environment 39(1): 15-35.

MENDONÇA, F. P., MAGNUSSON, W. E. \& ZUANON, J. 2005. Relationships between habitat characteristics and fish assemblages in small streams of Central Amazonia. Copeia 4: 751-764.

MODESTO, V., ILARRI, M., SOUZA, A. T., LOPES-LIMA, M., DOUDA, K., CLAVERO, M. \& SOUSA, R. 2018. Fish and mussels: Importance of fish for freshwater mussel conservation. Fish and Fisheries 19(2): 244-259.

PINDER, L. C. V. 1986. Biology of freshwater Chironomidae. Annual review of entomology 31(1): 1-23.

RICKLEFS, R. \& RELYA, R. 2016. A Economia da Natureza. 7 ed. GuanabaraKoogan, Rio de Janeiro. 
Costa, A.C. et al.

ROQUE, F. D. O., TRIVINHO-STRIXINO, S., JANCSO, M. \& FRAGOSO, E. N. 2004. Records of Chironomidae larvae living on other aquatic animals in Brazil. Biota Neotropica 4(2): 1-9. https://doi.org/10.1590/S167606032004000200018 (last access in 20/08/2020).

SILKNETTER, S., CREED, R. P., BROWN, B. L., FRIMPONG, E. A., SKELTON, J. \& PEOPLES, B. K. 2020. Positive biotic interactions in freshwaters: A review and research directive. Freshwater Biology 65(4): 811-832.

SYDOW, V. G., VILELLA, F. S., HARTZ, S. M. \& RODRIGUES, G. G. 2008. Ichthyocladius (Diptera, Chironomidae) on loricariid fishes in Atlantic Forest streams: influence of host size and corporal region on larval attachment. Acta Limnologica Brasiliensia 20(4): 333-337.

TERESA, F. B. \& CASATTI, L. 2012. Influence of forest cover and mesohabitat types on functional and taxonomic diversity of fish communities in Neotropical lowland streams. Ecology of Freshwater Fish 21(3): 433-442.

TOKESHI, M. 1993. On the evolution of commensalism in the Chironomidae. Freshwater Biology 29(3): 481-489.
TRIVINHO-STRIXINO, S. 2014. Ordem Diptera. Família Chironomidae. Guia de identificaçāo de larvas. In Insetos Aquático na Amazônia Brasileira: taxonomia, biologia e ecologia (N. Hamada, J. L. Nessimian, R. B. Querino, eds). Editora do Instituto Nacional de Pesquisas da Amazônia, Manaus, p.457-660.

VILELLA, F. S. 2002. Ecologia da comunidade aquática de um riacho de $1^{\text {a }}$ ordem da Mata Atlântica: Relações entre variáveis estruturais e bióticas em uma Reserva de Biosfera Tropical. Master's Dissertation, Federal University of São Carlos, São Carlos. https://repositorio.ufscar.br/bitstream/handle/ ufscar/1965/DissFSV.pdf? sequence=1 (last accessed on 12/01/2020).

WHITE, P. S., MORRAN, L. \& DE ROODE, J. 2017. Phoresy. Current Biology 27(12): R578-R580.

ZUANON, J. \& SAZIMA, I. 2005. Free meals on long-distance cruisers: the vampire fish rides giant catfishes in the Amazon. Biota Neotropica 5: 109-114. http:// dx.doi.org/10.1590/S1676-06032005000100012 (last accessed on 16/06/2020).

Received: $24 / 09 / 2020$

Revised: 13/06/2021

Accepted: 21/06/2021

Published online: 19/07/2021 